\title{
Functions of Epimedium on Regressed Oviduct and Follicles of Force Molted Layer Hens
}

\author{
Yu Guo, Shuying Huo*, Yurong Li, Shuang Zhang, Xianjun Wu, Luying Jiang, Qianhui Zhao, and Wenhui Xue \\ The College of Veterinary Medicine, Agricultural University of Hebei, Baoding 071001, China \\ *Corresponding author's Email: huoshuying@ 163.com; ORCID: 0000-0002-1744-8560
}

Received: 14 Apr. 2020

Accepted: 27 May. 2020

\begin{abstract}
In order to reveal the functions of Epimedium (EPI) on the recovery of the reproductive system of laying hens, 120 Hy-Line Brown laying hens (43-week-old) were forced molt through feed withdrawal for 14 days. After the molting period, layer hens were divided into four groups: Dark-control group in a dark environment without any treatment; dark-EPI group in a dark environment and with EPI treatment; light-control group without any treatment under normal illumination (16L: 8D); light- EPI group with EPI treatment under normal illumination (16L: 8D). EPI treatment was maintained for 15 days and each hen received $2 \mathrm{ml}$ of EPI extract $(1 \mathrm{~g} / \mathrm{mL})$ daily. The rate of egg production was calculated every day. At the end of the experiment, estrogen receptor alpha mRNA, estrogen receptor beta mRNA, and progesterone receptor mRNA in the albumen secreting part and uterus of the oviduct were detected by q-PCR, and the level of serum progesterone, estrogen and luteinizing hormone was measured by enzyme-linked immunosorbent assay. The results showed that EPI effectively improved the laying rate of hens both in dark groups and light groups by promoting the recovery of the oviduct and follicle maturation. In addition, EPI promoted the secretion of estrogen and progesterone both in dark and light groups and improved the expression of estrogen receptor alpha and progesterone receptor in the light group. The results of the experiment provide a good reference for using EPI to improve the development and recovery of the reproductive system of layer hens.
\end{abstract}

Key words: Epimedium, Forced molting, Layer hens, Oviduct

\section{INTRODUCTION}

The development of follicles and oviduct is crucial to the hens' laying abilities. Hen follicle development can be divided into three stages: primary $(0.8-2 \mathrm{~mm})$, prehierarchical (2-8 $\mathrm{mm})$, and preovulatory follicles (9-35 mm) (Rangel et al., 2014; Lin et al., 2019). The oviduct of hens develops normally only on the left side. The oviduct of the hen consists of five parts: infundibulum, albumen secreting part, isthmus, uterus, and vagina (Michailidis et al., 2011; Socha et al., 2018), each with unique functions morphologically. The albumen secreting part is the longest part of the oviduct that secretes most of the albumen (Li., 2007), and the uterus is responsible for the formation of eggshell membranes (Socha et al., 2018). Estrogen $\left(\mathrm{E}_{2}\right)$, follicle-stimulating hormone (FSH), and luteinizing hormone (LH) are crucial during the development of the reproductive system and the laying period. $\mathrm{E}_{2}$ is secreted by the membrane cells in the follicle, and its concentrations are the highest in the small yellow follicles (Rangel et al., 2014). $\mathrm{E}_{2}$ and progesterone $\left(\mathrm{P}_{4}\right)$ start the development of the oviduct (Zhao, 2018). The progesterone receptor (PR) is expressed on the fallopian tube and binds to $\mathrm{P}_{4}$. The activity of $\mathrm{E}_{2}$ depends on the estrogen receptor (ER) that has two subtypes of estrogen receptor alpha $(\mathrm{ER} \alpha)$ and estrogen receptor beta $(\mathrm{ER} \beta)$ (Miyagawa et al., 2014; Nirmali et al., 2019). FSH is secreted by basophilic cells in the anterior pituitary of birds. FSH can regulate follicle growth and drive the proliferation, growth, and differentiation of granulosa cells (Hunzicker-Dunn and Maizels, 2006; Uhm et al., 2010). Selection of prehierarchical follicles depends on levels of FSH and its receptor expressions (Lin et al., 2011). LH is a major hormone that promotes follicle maturation and excretion. FSH binds to its receptor on follicular granulosa cells, resulting in follicular differentiation, and then follicular membrane cells begin to express the $\mathrm{LH}$ receptor. This lays a foundation for the synthesis of E2 and ovulation (Tischkau et al., 2011). $\mathrm{P}_{4}$ is secreted by follicular granulosa cells and has positive associations with egg production (Wang, 2018).

The laying performance of layer hens is not always at its peak (Perry and Yousef., 2013). Many factors such 
as environmental stress, infectious bronchitis virus, and the aging of hens can lead to a decrease in egg production. In China, the use of hormonal drugs and antiviral western medicine in the production of food animals is not permitted.

One of the solutions for restoring performance and egg quality of laying hens is to induce the molting (Alodan and Mashaly, 1999). The process of molting is accompanied by the degeneration of the oviduct tract (Berry, 2003). Fasting is used as the main method of forced-molting (Han et al., 2019). Since light plays a major role in the development of the hen reproductive system (Liu et al., 2015), avoiding light along with forced molting can be used to accelerate the degradation of the oviduct.

Epimedium (EPI) is one of the most famous resources of Chinese herbal medicine (Zhang et al., 2008; Zhang et al., 2013). It is used to treat animals with reproductive diseases (Zhang et al., 2005). Flavonoids and polysaccharides are the main active components of EPI, which have the functions of enhancing immunity, anticancer, and anti-aging in traditional Chinese medicine (Liang et al., 2012). The total flavonoids of EPI have $\mathrm{E}_{2^{-}}$ like effects, which can thicken the endometrium of ovariectomized mice (Zhou et al., 2012). Epimedium may protect the testicles from damage by suppressing inflammation and oxidative stress (Cheng et al., 2019). The extraction methods of EPI include alkali extraction, ultrasonic extraction, hot water extraction, microwave extraction, organic solvent extraction, and supercritical fluid extraction (Li et al., 2014).

$\mathrm{E}_{2}$ controls the growth of the oviduct by regulating cell proliferation, differentiation, and egg cell protein synthesis (Socha et al., 2018). Similarly, EPI can promote the egg-laying performance of laying hens (Huo et al., 2018), but the impact of EPI on hens' reproductive system remains unclear. In this study, the forced molting method was used to degrade the hen's reproductive system, and then hens were treated with EPI to study the functions of EPI on the repairing of oviduct and follicles and secreting of reproductive hormones. Since light has a great influence on the development of the reproductive system of hens, lighting was considered as a variable for comparison.

\section{MATERIALS AND METHODS}

\section{Ethical approval}

This study was approved by the Experimental Animal Ethics Committee of Hebei Agricultural University (certificate code: 2020013).

\section{Extraction and determination of Epimedium}

Epimedium koreanum was purchased from the Anguo Oriental Medicine City, Hebei, China. The active components of the EPI were obtained through alcohol extracting by an ultrasonic method (Zhang et al., 2008). First, EPI was crushed into powder, added in $65 \%$ ethanol solution at a ratio of $1: 30$, and then rested at room temperature for $60 \mathrm{~min}$. The effective components of the EPI were extracted twice in the ultrasonic purification device at $60{ }^{\circ} \mathrm{C}$ for $60 \mathrm{~min}$, filtrated with the filter paper. The filtered solution was centrifuged at $3000 \mathrm{r} / \mathrm{min}$ for 10 $\min$ and then concentrated to $1 \mathrm{~g} / \mathrm{mL}$ by a rotary evaporator at $80{ }^{\circ} \mathrm{C}$, stored at $4{ }^{\circ} \mathrm{C}$. The quantitative determination of the total flavonoids of EPI was measured by colorimetry at $496 \mathrm{~nm}$, with rutin as the reference and aluminum nitrate as the chromogenic agent (Guo et al., 2019).

\section{Animal grouping and treatment}

A total of 120 Hy-Line Brown layer hens at 43 weeks of age were provided by Ding Nong Corporation of Hebei, Baoding, China. Layer hens were weighed before forced molting and raised on the poultry breeding farm of Hebei Agricultural University. They were divided into four equal groups of 30 hens and three replicates for each group. Then all hens were placed in an environment shaded by a dark nylon cover; and received no food for 14 days but they could drink water freely. Forced molting lasted for 14 days until the average body weight of layer hens lost a third and egg production completely ceased. From the 15th day of the experiment, all the hens were allowed to recover with ad libitum access to food and water, according to the nutrient suggestions for layer hens (Clark et al., 2019). Dark control (D-CON) group was still kept in a dark feeding environment without any treatment; dark EPI (D-EPI) group was kept in a dark feeding environment and each hen was given $2 \mathrm{~mL}$ of EPI extract $(1 \mathrm{~g} / \mathrm{mL})$ by gavage every day; light control (L-CON) group was without EPI treatment under normal illumination (16L: 8D); light-EPI (L-EPI) group received $2 \mathrm{~mL}$ EPI extract $(1 \mathrm{~g} / \mathrm{mL})$ per hen by gavage every day, under normal illumination (16L: 8D). During the experiment, egg production was recorded every day, and the laying rate of each group was obtained by dividing the number of eggs laid during the day by the number of hens. The EPI treatment on layer hens was maintained for 15 days. At the end of the experiment, the hens of each group were weighed and then sacrificed with bleeding of the carotid artery. Blood was collected and serum was isolated for $\mathrm{P}_{4}, \mathrm{E}_{2}$, and $\mathrm{LH}$ detection. The oviduct of hens was 
taken out for weighing and length measurement. The relative weight of the oviduct to body weight was calculated. The uterus and albumen secreting parts were separated and half of the tissue samples were stored at -80 ${ }^{\circ} \mathrm{C}$ for later real-time polymerase chain reaction (q-PCR). The rest tissue fragments were fixed in a $4 \%$ paraformaldehyde solution for histomorphology observation.

\section{Histomorphology observation of albumen secreting part and uterus}

The albumen secreting part and uterus were fixed in a 4\% paraformaldehyde solution overnight and washed by pH 7.4 phosphate buffer saline (PBS). Routine dehydration and paraffin embedding were done. Histological sections of $5 \mu \mathrm{m}$ thickness were sliced by an automatic slicer for hematoxylin and eosin (H\&E) staining. Images were observed via a digital camera (Leica DFC320).

mRNA expressions of estrogen and progesterone receptors in albumen secreting part and uterus

The total RNA was extracted by the Trizol reagent of a commercial RNA assay kit (Invitrogen Co., USA) according to the manufacturer's instructions. Reverse transcription was performed with $25 \mu$ of the reaction mixtures containing $10 \mu \mathrm{l}$ of total RNA extraction solution, $2 \mu \mathrm{l}$ Olig (dT) primer, $2 \mu \mathrm{l}$ RNase inhibitor, $5 \mu \mathrm{l}$ dNTPs, $5 \mu 15 \times$ M-MLV buffer and $1 \mu \mathrm{l}$ M-MLV reverse transcriptase. Before $1 \mu \mathrm{l}$ M-MLV $(100 \mathrm{U})$ reverse transcriptase was added, other components were incubated at $65^{\circ} \mathrm{C}$ for $5 \mathrm{~min}$ and then placed on ice for $5 \mathrm{~min}$. After 1 $\mu 1$ M-MLV (100 U) reverse transcriptase was added, reverse transcription was conducted at $42{ }^{\circ} \mathrm{C}$ for $1 \mathrm{~h}$.

Expression of ER $\alpha, E R \beta$, and PR was detected by qPCR on a fluorescence ration PCR instrument (CFX96 Bio-Rad, CA, USA). The q-PCR reaction was performed with $25 \mu \mathrm{l}$ of the reaction mixtures containing $12.5 \mu \mathrm{l}$ of 2 $\times$ M5 Hiper SYBR Premix Es Taq (Mei5 Biotechnology, Beijing, China), $2 \mu \mathrm{l}$ of cDNA, $9.5 \mu \mathrm{lddH} 2 \mathrm{O}$ and $0.5 \mu \mathrm{l}$ of each forward and reverse primer. The primers (Table 1) were designed based on sequences in GenBank using Primer Premier 5.0 software and manufactured by Sangon Biotech Company (Shanghai, China).

They followed the following procedure respectively: $95^{\circ} \mathrm{C}$ for $3 \mathrm{~min} ; 95^{\circ} \mathrm{C}$ for $5 \mathrm{~s}$ and $60{ }^{\circ} \mathrm{C}$ for $30 \mathrm{~s}$ for 40 cycles. The PCR efficiency was close to $100 \%$, indicating the $2^{-\triangle \Delta C T}$ method was applicable to the calculation of relative gene expression levels (Zhao et al., 2018). Three samples were amplified and the data were normalized to glyceraldehyde phosphate dehydrogenase (GAPDH) expression.

\section{Determination of progesterone, estrogen and luteinizing hormone in serum}

P4, E2, and LH were detected by enzyme-linked immunosorbent assay (ELISA) with the Hen Progesterone ELISA Kit (MLBIO, China). The serum was removed from $-80^{\circ} \mathrm{C}$, and the standard, blank diluent, and samples were added to the ELISA Kit. All procedures were conducted according to the manufacturer's protocol. The absorbance was measured at $600 \mathrm{~mm}$, a standard curve was established, and the hormone content of each sample was calculated.

\section{Statistical analysis}

All of the experiments were repeated at least three times, and the results were expressed as means \pm standard error. Statistical analyses were performed on the SPSS software V22.0 (SPSS Inc., Chicago, IL, USA). All data were analyzed by one-way analysis of variance (ANOVA) to determine the differences among the groups. Mean values were considered significantly different at $\mathrm{p}<0.05$.

Table 1. Primers used for detection of the glyceraldehyde phosphate dehydrogenase (GAPDH), estrogen receptor alpha (ER $\alpha$ ), estrogen receptor beta (ER $\beta$ ) and progesterone receptor (PR) genes by q-PCR

\begin{tabular}{llcc}
\hline Target gene & Primer sequences (5'-3') & Size (base pair) & GenBank accession number \\
\hline$G A P D H-F$ & ACGTCGCACTGGATTTCGAG & 82 & NM_204305 \\
$G A P D H-R$ & TGTCAGCAATGCCAGGGTAC & 99 & NM_205183.2 \\
\hline$E R \alpha-F$ & GTACGGCTCTACTACACTCAGTTATGC & & \\
\hline$E R-R$ & GGGCTTGGTGGGACATTGTTCAG & NM_204794.2 \\
$E R \beta-R$ & CCCTCCCAGCAGCAAACAACTC & 148 & \\
\hline$P R-F$ & TCAACATCTCCAGCAGCAAGTCATAC & & M37518.1 \\
$P R-R$ & CCTGGACGGGCTGCTCTACC & 89 & \\
\hline
\end{tabular}




\section{RESULTS}

\section{Effects of Epimedium on egg-laying rates}

On the $14^{\text {th }}$ day of the experiment, egg-laying rates of all four groups were $0 \%$ because of the oviduct atrophy and follicular degeneration by forced molting. From the 15th day of experiment with normal feeding, layer hens of L-CON and L-EPI groups began to lay eggs on the 25th day. Laying rates of the L-EPI group were higher than that of the L-CON group from the 25th day to the 30th day. On the 30th day, laying rates of the D-CON group was the lowest, and the D-EPI group had an extremely higher laying rate than the $\mathrm{D}-\mathrm{CON}$ group $(\mathrm{P}<0.01)$. As shown in figure 1, the L-EPI group had the highest rate of laying, followed by L-CON, D-EPI, and D-CON group. The results showed that EPI can improve the laying rate of layer hens both in dark and light environments.

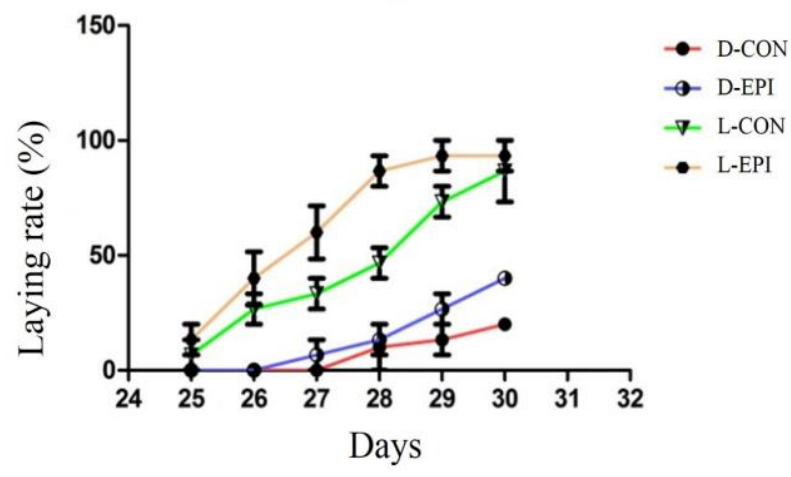

Figure 1. The daily laying rate of laying hens subjected to forced molting and treatment. EPI: Epimedium. D-CON: without EPI treatment in a dark environment; D-EPI: with EPI treatment in a dark environment; L-CON: without EPI treatment under normal illumination; L-EPI: with EPI treatment under normal illumination. Two milliliters of EPI extract $(1 \mathrm{~g} / \mathrm{mL})$ was daily administered each chicken for 15 days.

Effect of Epimedium on the development and recovery of follicle and oviduct

On the 30th day, the follicles in the D-CON group grew sluggishly, a large number of small white follicles existed and the oviducts were found still to be atrophied and not to return to normal (Figure 2A). However, large white follicles and small yellow follicles were evident in the D-EPI group, oviduct developed to nearly normal (Figure 2B). In the L-CON and L-EPI groups, follicles growth returned to normal, follicles in different stages of development were present and the oviducts of both groups developed to normal (Figure 2C and 2D). The relative weights of oviduct to body weight of layer hens from the D-CON group were remarkably lower than other groups on the 30th day $(\mathrm{P}<0.01)$, as shown in figure $2 \mathrm{~A}$. The relative weights of oviduct in the D-EPI group were lower than L-EPI and L-CON group ( $<<0.05)$. In addition, the average length of oviduct in the D-CON group was remarkably shorter than that in the other groups $(\mathrm{P}<0.01$, figure $3 \mathrm{~B}$ ) and there was no significant difference in the average length of oviduct among D-EPI, L-CON, and LEPI group.

\section{Histomorphology of albumen secreting part and uterus of oviduct}

On the 30th day of the experiment, it was found that columnar ciliated epithelial cells in the uterus and albumen secreting part were normally arranged in D-EPI, L-CON and L-EPI group, with intact serosa observed, and the cilia in the D-CON group were thinner (Figure 4). In addition, there was corresponding atrophy of the uterus and albumen secreting part in the D-CON group. The D-EPI group had a slight deficit in cilia development compared to the L-CON and L-EPI groups. In the D-EPI, L-CON and L-EPI group, the uterus and albumen secreting part showed normal arrangement of columnar ciliated epithelial cells, while the D-CON group showed dysplasia of cilia (Figure 4).

mRNA expressions of estrogen and progesterone receptors in albumen secreting part and uterus

The results showed that the relative value of ER $\alpha$ mRNA to GAPDH in the D-CON group was the lowest both in the albumen secreting part and uterus $(\mathrm{P}<0.01)$, the D-EPI group had no significant difference compared to D-CON group. The expression of ER $\alpha$ mRNA in the L$\mathrm{CON}$ and L-EPI group was higher than that in D-CON and D-EPI group, and the L-EPI group had an extremely higher value compared to L-CON group $(\mathrm{P}<0.05)$ (Figure $5 \mathrm{~A}$ and $\mathrm{D})$. There was no significant difference in terms of the expression of ER $\beta$ mRNA in the albumen secreting part and uterus of the four groups $(\mathrm{P}>0.05)$ (Figure $5 \mathrm{~B}$ and $E$ ). The relative value of PR mRNA in D-CON and DEPI group had no significant difference both in albumen secreting part and uterus, while expression of PR mRNA in L-CON and L-EPI group were both higher than that in D-CON and D-EPI group, and PR mRNA in L-EPI group was extremely higher than in L-CON group $(\mathrm{P}<0.01)$ (Figure $5 \mathrm{C}$ and $\mathrm{F}$ ).

Effects of Epimedium on the level of progesterone, estrogen and luteinizing hormone in serum

The results (Table 2) showed that concentration of $\mathrm{P}_{4}$ in the serum of D-CON group was significantly lower than that in the other three groups, and $\mathrm{P}_{4}$ level was higher in LEPI group compared to D-EPI $(\mathrm{P}<0.05)$, but was lower than that of L-CON group $(\mathrm{P}<0.05)$. $\mathrm{E}_{2}$ concentration of serum in the L-CON group and L-EPI group was higher than that in the D-CON group and D-EPI group $(\mathrm{P}<0.01)$. The concentration of $E_{2}$ in the D-EPI and L-EPI group was higher than that in control groups $(\mathrm{P}<0.05)$. The serum concentration of LH in the four groups was not significantly different $(\mathrm{P}>0.05)$. 

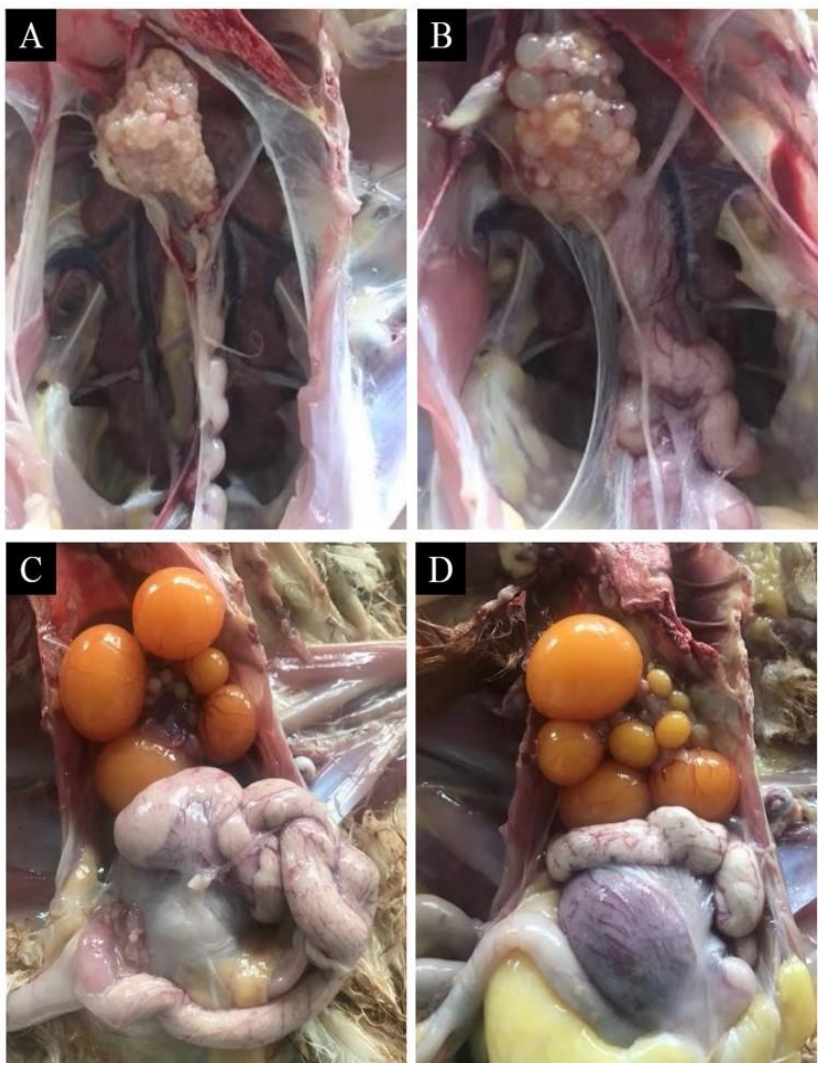

Figure 2. Ovarian follicles and oviducts of laying hens subjected to forced molting and treatment (A: D-CON group; B: D-EPI group; C: L-CON group; D: L-EPI group). EPI: Epimedium. D-CON: without EPI treatment in a dark environment; D-EPI: with EPI treatment in a dark environment; L-CON: without EPI treatment under normal illumination; L-EPI: with EPI treatment under normal illumination. Two milliliters of EPI extract (1 $\mathrm{g} / \mathrm{mL}$ ) was daily administered each chicken for 15 days.
A)



B)

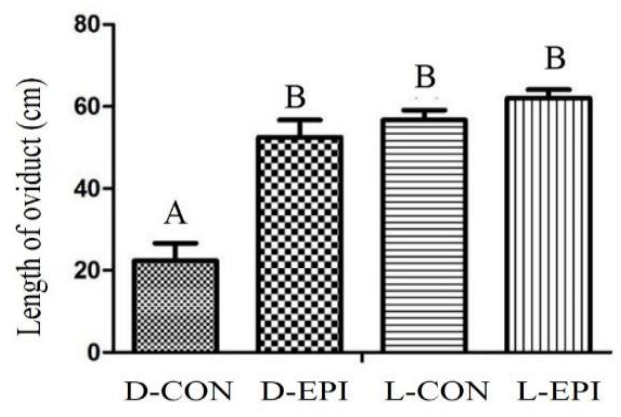

Figure 3. Effects of Epimedium on the relative weight and average length of oviduct of laying hens treated in different groups after forced molting. EPI: Epimedium. DCON: without EPI treatment in a dark environment; DEPI: with EPI treatment in a dark environment; L-CON: without EPI treatment under normal illumination; L-EPI: with EPI treatment under normal illumination. Two milliliters of EPI extract $(1 \mathrm{~g} / \mathrm{mL})$ was daily administered each chicken for 15 days. $^{\mathrm{a}, \mathrm{b}, \mathrm{c}}$ on the bar means $\mathrm{P}<0.05$ and $^{\mathrm{A}, \mathrm{B}, \mathrm{C}}$ means $\mathrm{P}<0.01$.

Table 2. Serum concentration of the progesterone, estrogen and luteinizing hormone in layer chickens treated in different groups after 14-day forced molting

\begin{tabular}{lcccc}
\hline Parameters & D-CON & D-EPI & L-CON & L-EPI \\
\hline Progesterone $(\mathrm{pmol} / \mathrm{L})$ & $267.7 \pm 38.96^{\mathrm{Aa}}$ & $493.65 \pm 105.92^{\mathrm{Ab}}$ & $728.06 \pm 131.04^{\mathrm{Bc}}$ & $584.56 \pm 26.49^{\mathrm{Ad}}$ \\
Estrogen $(\mathrm{pg} / \mathrm{mL})$ & $40.57 \pm 5.85^{\mathrm{Aa}}$ & $71.74 \pm 13.21^{\mathrm{Ab}}$ & $136.75 \pm 40.77^{\mathrm{Bc}}$ & $153.32 \pm 29.67^{\mathrm{Bd}}$ \\
luteinizing hormone $(\mathrm{pg} / \mathrm{mL})$ & $22.11 \pm 4.56$ & $43.93 \pm 15.16$ & $47.05 \pm 14.27$ & $54.75 \pm 9.55$ \\
\hline
\end{tabular}

EPI: Epimedium. D-CON: without EPI treatment in a dark environment; D-EPI: with EPI treatment in a dark environment; L-CON: without EPI treatment under normal illumination; L-EPI: with EPI treatment under normal illumination. Two milliliters of EPI extract $(1 \mathrm{~g} / \mathrm{mL})$ was daily administered each chicken for 15 days. ${ }^{\text {a, b, c; }}$ Means within a row with different superscripts differ significantly $(\mathrm{P}<0.05)$; ${ }^{\mathrm{A}, \mathrm{B}, \mathrm{C} ;}$ Means within a column with different superscripts differ highly significantly $(\mathrm{P}<0.01)$. 

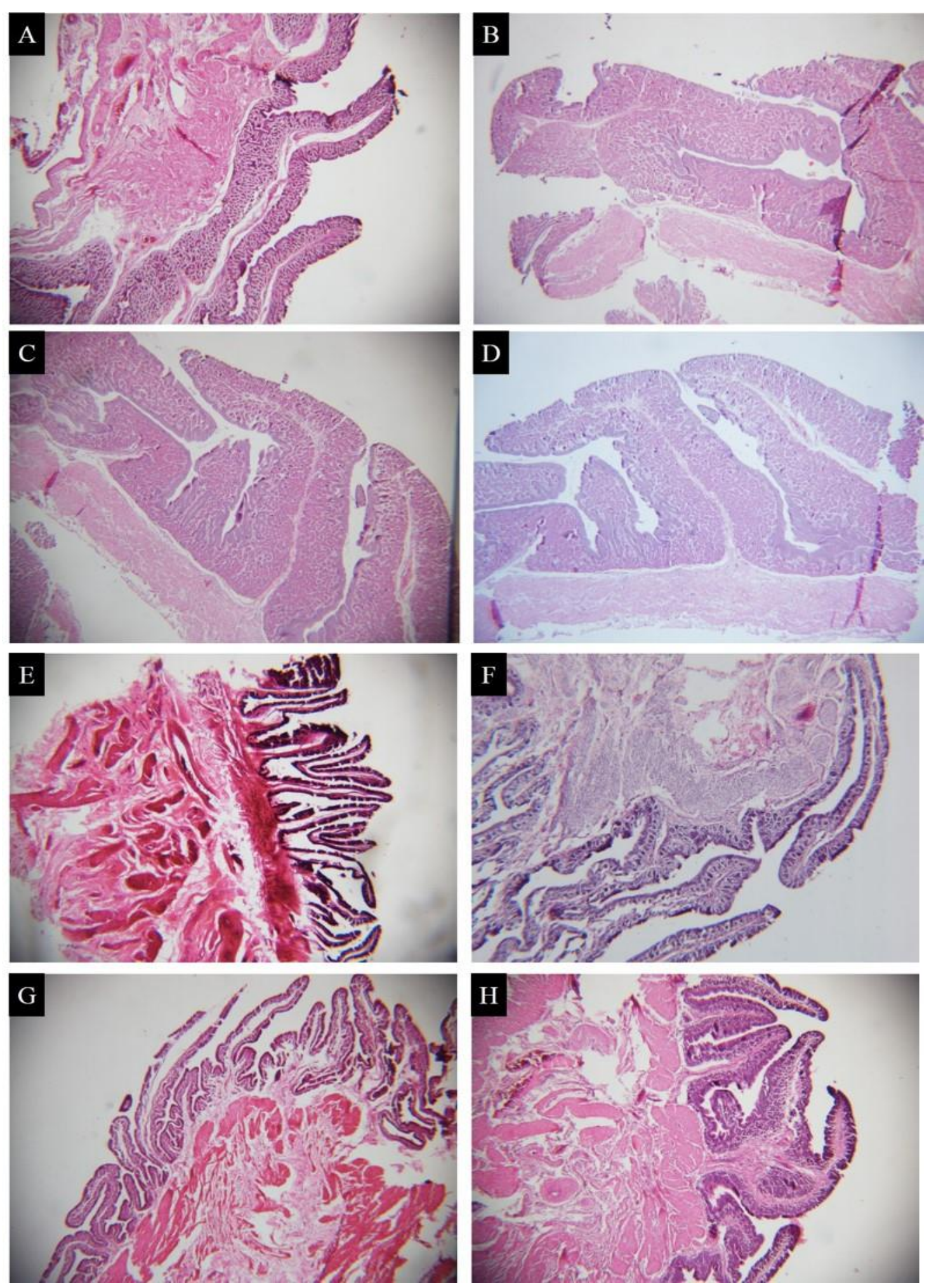

Figure 4. Histomorphology of albumen secreting part and uterus of oviduct of laying chickens treated in different groups after forced molting. A, B, C, and D are albumen secreting part of oviduct in D-CON, D-EPI, L-CON, and L-EPI groups, respectively $(\mathrm{H} \& \mathrm{E}, 10 \times)$. E, F, G, and $\mathrm{H}$ are uterus of the oviduct in D-CON, D-EPI, L-CON and L-EPI group respectively (H\&E, 10x). EPI: Epimedium. D-CON: without EPI treatment in a dark environment; D-EPI: with EPI treatment in a dark environment; L-CON: without EPI treatment under normal illumination; L-EPI: with EPI treatment under normal illumination. Two milliliters of EPI extract $(1 \mathrm{~g} / \mathrm{mL})$ was daily administered each chicken for 15 days. 
A)

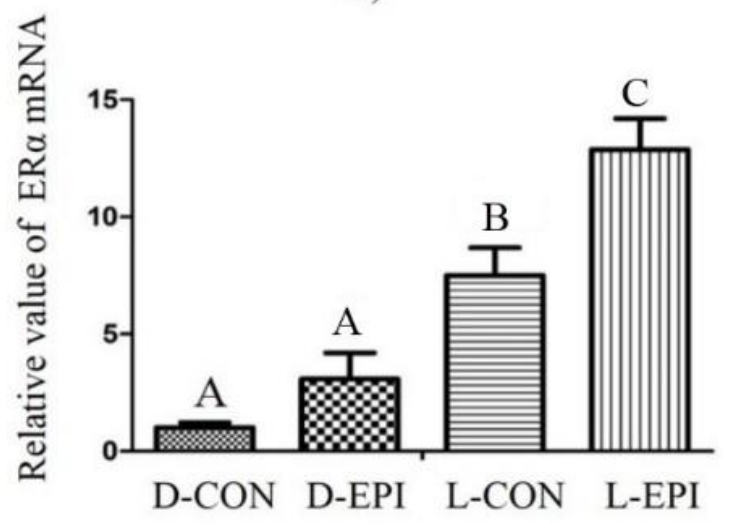

C)

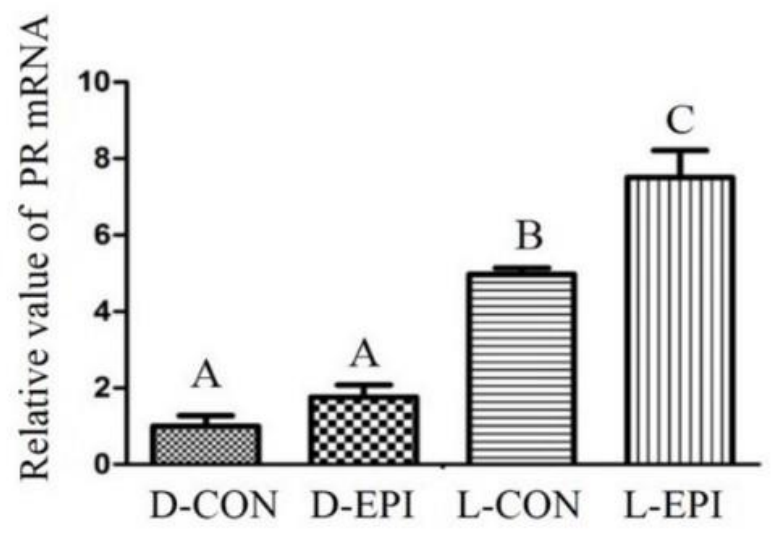

E)

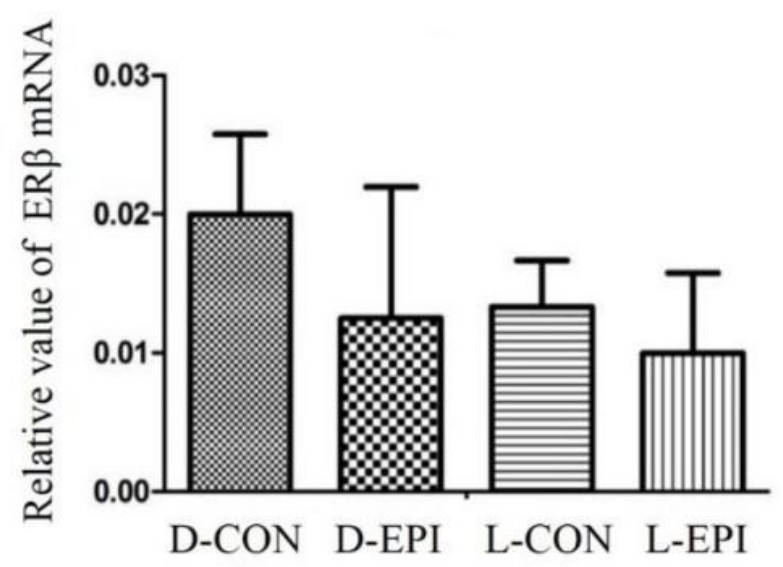

B)

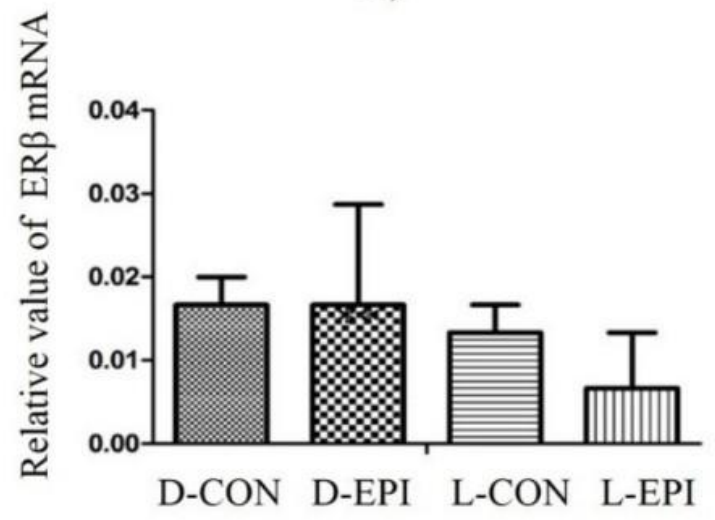

D)

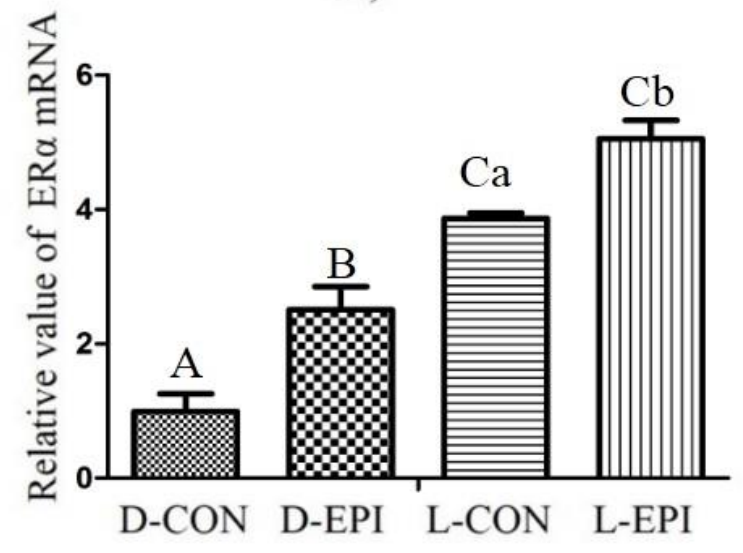

F)

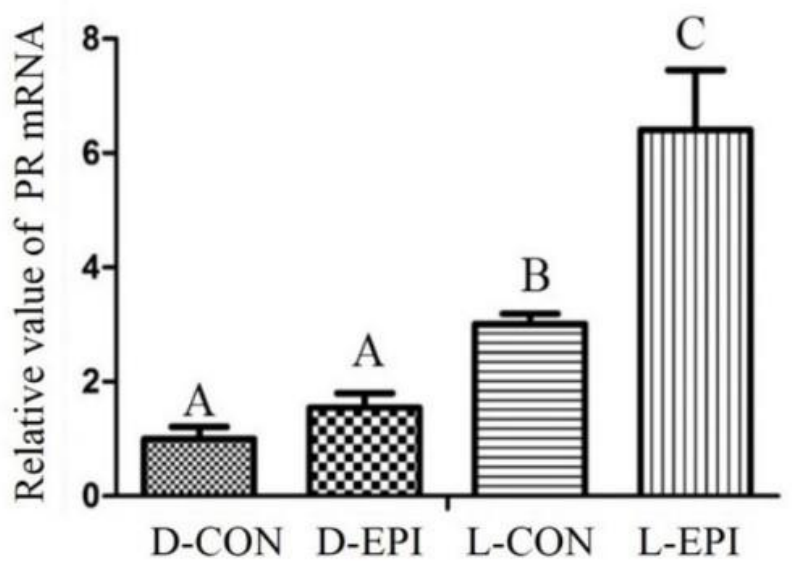

Figure 4. Effects of Epimedium on mRNA expression of estrogen receptor alpha (ER $\alpha)$, estrogen receptor beta (ER $\beta$ ), and progesterone receptor (PR) in albumen secreting part and uterus of laying hens in different treatment groups after forced molting. A, B, C: The expression of ER $\alpha, E R \beta$, and PR mRNA in the albumen secreting part. D, E, F: The expression of ER $\alpha$, ER $\beta$, and PR mRNA in the uterus. EPI: Epimedium. D-CON: without EPI treatment in a dark environment; D-EPI: with EPI treatment in a dark environment; L-CON: without EPI treatment under normal illumination; L-EPI: with EPI treatment under normal illumination. Two milliliters of EPI extract $(1 \mathrm{~g} / \mathrm{mL})$ was daily administered each chicken for 15 days.

$\mathrm{a}, \mathrm{b}, \mathrm{c}$ on the bar means $\mathrm{P}<0.05{ }^{\mathrm{A}, \mathrm{B}, \mathrm{C}}$ on the bar means $\mathrm{P}<0.01$. 


\section{DISCUSSION}

In this study, the active components of EPI were extracted by alcohol with an ultrasonic method, a better way for the extraction of the total flavonoids of EPI. Layer hens, whose oviduct and follicles were atrophic after forced molting, were fed with EPI extracts in dark and light environments and the laying rates extremely increased both in the D-EPI group and the L-EPI group. The results demonstrated that EPI extracts have the functions of improving the development of the reproductive system of layer hens, especially in the light environment. Previous studies have revealed that total flavonoids of EPI can cure premature ovarian insufficiency, and the therapeutic targets are ESR1, AR, ESR2, KDR, CYP19A1, and ESRRG (Zhao et al., 2019). EPI has been reported to restore the oxidative damage of mouse testis and maintain sperm motility and has a protective effect on the reproductive function of male mice (Yuan et al., 2014).

The number of eggs a hen lays is determined by the development of follicles in ovary, and the quality of eggs such as the hardness of the shell is determined by the oviduct (Socha et al., 2018). After treatment with EPI, the oviduct of layer hens in the D-EPI group was fully developed, and the follicles included primary follicles and large white follicles and small yellow follicles. Some layers contained preovulatory follicles and mature follicles and began to lay eggs. The oviduct in the D-CON group was severely atrophic, and the follicles were most primary follicles and small white follicles without further development. Only a few layers began to lay eggs. The L$\mathrm{CON}$ and L-EPI groups were raised under the environment of light, which has a great influence on the development of the hen's reproductive system. Therefore, the development of the ovary and oviduct in L-CON and L-EPI groups was very normal. It is worth noting that there were significantly more prehierarchical follicles in the D-EPI and L-EPI groups of layers treated with EPI than in D$\mathrm{CON}$ and L-CON groups.

According to the results of the percentage of oviduct weight to body weight, the length of oviduct, and the rate of egg production, the impact of EPI and light on the development of the hen's reproductive system and the rate of egg production is significant. Light has a bigger effect than EPI; while EPI can build on that.

The biological activity of EPI can be largely mediated through $E_{2}$ receptor-mediated pathway or blocked by ER blockers (Zhang et al., 2016). $\mathrm{E}_{2}$ is closely related to the development of oviducts and ovaries, and $\mathrm{P}_{4}$ is positively associated with ovulation. The determination of expression of ER $\alpha, E R \beta$, and PR mRNA in the albumen secreting part and the uterus of the oviduct showed that the expression of ER $\alpha$ mRNA was significantly higher under the action of EPI, especially in the light environment. ER $\beta$ mRNA was poorly expressed both in dark groups and in light groups. The impact of light on PR mRNA expression appeared to be better than that of EPI, especially when the sample was treated with EPI under light conditions. The results indicated that the impacts of EPI on the expression of ER and PR were not obvious without light; however, it became stronger under the light conditions. From the results, it can be inferred that ER $\alpha$ and PR are the crucial receptors mediating the process of $\mathrm{E}_{2}$ and $\mathrm{P}_{4}$ and improving the development of oviduct, and EPI participated in the process. The measurement of $\mathrm{E}_{2}$ and $\mathrm{P}_{4}$ in serum showed that EPI improved the secretion of endogenous hormones both in dark and light groups. The impact of light was greater than that of EPI. However, both light and EPI had a small impact on the secretion of LH. It was found that EPI and light could promote the development and proliferation of epithelial cells in the oviduct.

EPI promoted the development of follicles from primary follicles to prehierarchical follicles. Hormones that promote follicular growth and differentiation include FSH and LH, and cytokines include insulin-like growth factor family (IGF) (Roberts et al., 1994), transforming growth factor- $\beta$ (TGF- $\beta$ ) (Johnson et al., 2004; Woods et al., 2005), epidermal growth factor (EGF) (Onagbesan et al., 1994; Lin et al., 2011), fibroblast growth factor (FGF) (Miyahara et al., 2016), and tumor necrosis factor- $\alpha$ (TNF$\alpha)$ (Bornstein et al., 2004). The experimental results showed that EPI and light had no significant impacts on LH secretion. Hence, EPI is likely to have a similar effect like FSH or other follicle-promoting cytokines.

\section{CONCLUSIONS}

This study may aid the development of treatment drugs for reproductive diseases in layer hens.

EPI has the potential functions to increase egg production by improving the recovery of oviducts and maturation of follicles. EPI could promote the secretion of endogenous $\mathrm{E}_{2}$ and $\mathrm{P}_{4}$, especially in light environment. Also, EPI could improve the expression of ER $\alpha$ mRNA and PR mRNA in the oviduct. 


\section{DECLARATIONS}

\section{Competing interests}

The authors have declared that no competing interest exists.

\section{Authors' contributions}

Shuying $\mathrm{H}$ and $\mathrm{Yu} \mathrm{G}$ designed research and wrote the paper. Yurong $\mathrm{L}$ and Xianjun $\mathrm{W}$ analyzed data. Shuang $\mathrm{Z}$ and Luying $\mathrm{J}$ conceived of the study and participated in its coordination. Qianhui $Z$ and Wenhui $X$ contributed vital new reagents. All authors read and approved the final manuscript.

\section{Acknowledgments}

This project was supported by the Fund for Scientific Research and Development of Agricultural University of Hebei, Project No: JY2018005.

\section{REFERENCES}

Alodan MA and Mashaly MM (1999). Effect of induced molting in laying hens on production and immune parameters. Poultry Science, 78: 171-177. DOI: https://doi.org/10.1093/ps/78.2.171

Berry WD (2003). The physiology of induced molting. Poultry Science, 82: 971-980. DOI: https://doi.org/10.1093/ps/82.6.971.

Bornstein SR, Rutkowski H and Vrezas I (2004). Cytokines and steroidogenesis. Molecular and Cellular Endocrinology, 215: 135141. DOI: https://doi.org/10.1016/j.mce.2003.11.022.

Cheng Y, Yang Z, Shi J, Yang J, Zhao J, He Y, and Qi M (2019). Total flavonoids of Epimedium ameliorates testicular damage in streptozotocin-induced diabetic rats by suppressing inflammation and oxidative stress. Environmental Toxicology, 35: 268-276. DOI: https://doi.org/10.1002/tox.22864.

Clark CEF, Akter Y, Hungerford A, Thomson, P, Islam MR, Groves PJ and O'Shea CJ (2019). The intake pattern and feed preference of layer hens selected for high or low feed conversion ratio. PloS one, 14: e0222304. DOI: https://doi.org/10.1371/journal.pone.0222304.

Guo C, Zhang G, Lin X, Zhao D, Zhang C and Mi Y (2019). Reciprocal stimulating effects of bFGF and FSH on chicken primordial follicle activation through Akt and ERK pathway. Theriogenology, 132: 2735. DOI: https://doi.org/10.1016/j.theriogenology.2019.04.005.

Han GP, Lee KC, Kang HK, Oh HN, Sul WJ and Kil DY (2019). Analysis of excreta bacterial community after forced molting in aged laying hens. Asian-Australasian Journal of Animal Sciences, 32: 1715-1724. DOI: https://doi.org/10.5713/ajas.19.0180.

Hunzicker-dunn M and Maizels ET (2006). FSH signaling pathways in immature granulosa cells that regulate target gene expression: Branching out from protein kinase A. Cellular Signalling, 18: 13511359. DOI: https://doi.org/10.1016/j.cellsig.2006.02.011.

Huo SY, Kang JM, Li YR and Wu XJ (2018). Effects of "yi mu san" on fallopian tube repair and egg laying performance of laying hens. China Poult, 40: 53-56. Available at: http://kns.cnki.net/kcms/detail/detail.aspx?FileName=ZSYX201912 031\&DbName= DKFX2019

Johnson AL, Bridgham JT and Woods DC (2004). Cellular mechanisms and modulation of activin a- and transforming growth factor betamediated differentiation in cultured hen granulosa cells. Biology of Reproduction, $\quad 71$ : 1844-1851. DOI: https://doi.org/10.1095/biolreprod.104.032573.

Li J (2007). Morphological study on the occurrence of chicken fallopian tube. master, Yanbian University. Available at:
http://kns.cnki.net/kns/detail/detail.aspx?FileName $=2007183808 . n h$ $\&$ DbName $=$ CMFD2008

Li Q, Li X, Wei Y, Fan Y, Chen L, Zhang HY and Zhao TZ (2014). Extraction of total flavonoid from Herba epimedii maxim using alkali solution. Natural Products Research and Development, 26: 1141-1144 Available http://kns.cnki.net/kcms/detail/detail.aspx?FileName=TRCW20140 $7034 \&$ DbName $=$ CJFQ2014.

Liang Q, Wei G, Chen J, Wang Y and Huang H (2012). Variation of medicinal components in a unique geographical accession of horny goat weed Epimedium sagittatum maxim. Molecules, 17: 1334513356. DOI: https://doi.org/10.3390/molecules 171113345 .

Lin JX, Jia YD and Zhang CQ (2011). Effect of epidermal growth factor on follicle-stimulating hormone-induced proliferation of granulosa cells from chicken prehierarchical follicles. Journal of Zhejiang University Science B, 12: 875-883. DOI: https://doi.org/10.1631/jzus.B1100023.

Lin X, Ma Y, Qian T, Yao J, Mi Y and Zhang C (2019). Basic fibroblast growth factor promotes prehierarchical follicle growth and yolk deposition in the chicken. Theriogenology, 139: 90-97. DOI: https://doi.org/10.1016/j.theriogenology.2019.07.025.

Liu L, Li D, Gilbert ER, Xiao Q, Zhao X, Wang Y, Yin H and Zhu Q (2015). Effect of monochromatic light on expression of estrogen receptor (ER) and progesterone receptor (PR) in ovarian follicles of chicken. Plos one, 10: e0144102. DOI: https://doi.org/10.1371/journal.pone.0144102.

Michailidis G, Theodoridis A and Avdi M (2011). Effects of sexual maturation and salmonella infection on the expression of toll-like receptors in the chicken vagina. Animal Reproduction Science, 123: 234-241. DOI: https://doi.org/10.1016/j.anireprosci.2011.01.010

Miyagawa S, Lange A, Hirakawa I, Tohyama S, Ogino Y, Mizutani T, Kagami Y, Kusano T, Ihara M, Tanaka H et al (2014). Differing species responsiveness of estrogenic contaminants in fish is conferred by the ligand binding domain of the estrogen receptor. Environmental Science \& Technology, 48: 5254-5263. DOI: 10.1021/es5002659.

Miyahara D, Oishi I, Makino R, Kurumisawa N, Nakaya R, Ono T, Kagami $\mathrm{H}$ and Tagami T (2016). Chicken stem cell factor enhances primordial germ cell proliferation cooperatively with fibroblast growth factor 2. Journal of Reproduction and Development, 62: 143-149. DOI: https://doi.org/10.1262/jrd.2015-128.

Nirmali WKR, Warnakula L, Cooray R, Hapuarachchi NS and Magamage MPS (2019). Determination of testicular estrogen receptor alpha expression of male chickens (Gallus domesticus) with age. Vet World, 12: 994-997. DOI: https://doi.org/10.14202/vetworld.2019.994-997.

Onagbesan OM, Gullick W, Woolveridge I and Peddie MJ (1994). Immunohistochemical localization of epidermal growth factor receptors, epidermal-growth-factor-like and transforming-growthfactor-alpha-like peptides in chicken ovarian follicles. Journal of Reproduction and Fertility, 102: 147-153. DOI: https://doi.org/10.1530/jrf.0.1020147.

Perry JJ and Yousef AE (2013). Factors affecting thermal resistance of Salmonella enterica serovar Enteritidis oda 99-30581-13 in shell egg contents and use of heat-ozone combinations for egg pasteurization. Journal of Food Protection, 76: 213-219. DOI: https://doi.org/10.4315/0362-028X.JFP-12-324.

Rangel PL, Rodriguez A, Gutierrez K, Sharp PJ and Gutierrez CG (2014). Subdominant hierarchical ovarian follicles are needed for steroidogenesis and ovulation in laying hens (Gallus domesticus). Animal Reproduction Science, 147: 144-153. DOI: https://doi.org/10.1016/j.anireprosci.2014.04.011.

Roberts RD, Sharp PJ, Burt DW and Goddard C (1994). Insulin-like growth factor-i in the ovary of the laying hen: Gene expression and biological actions on granulosa and thecal cells. General and Comparative Endocrinology, 93: 327-336. DOI: https://doi.org/10.1006/gcen.1994.1037. 
Socha JK, Saito N, Wolak D, Sechman A and Hrabia A (2018). Expression of aquaporin 4 in the chicken oviduct following tamoxifen treatment. Reproduction in Domestic Animals, 53: 13391346. DOI: https://doi.org/10.1111/rda.13248.

Tischkau SA, Howell RE, Hickok JR, Krager SL and Bahr JM. (2011). The luteinizing hormone surge regulates circadian clock gene expression in the chicken ovary. Chronobiology International, 28: 10-20. DOI: https://doi.org/10.3109/07420528.2010.530363.

Uhm SJ, Gupta MK, Yang JH, Chung HJ, Min TS and Lee HT (2010). Epidermal growth factor can be used in lieu of follicle-stimulating hormone for nuclear maturation of porcine oocytes in vitro. Theriogenology, 73: 1024-1036. DOI: https://doi.org/10.1016/j.theriogenology.2009.11.029.

Wang P (2018). Egg laying performance and regulation of reproductive hormones in danzhou chickens. Master, University Of Hainan. Available

http://kns.cnki.net/kns/detail/detail.aspx?FileName=1018193108.nh $\& D b N a m e=$ CMFD2019

Woods DC, Haugen MJ and Johnson AL (2005). Opposing actions of TGFbeta and map kinase signaling in undifferentiated hen granulosa cells. Biochemical and Biophysical Research Communications, 336: 450-457. https://doi.org/10.1016/j.bbrc.2005.08.107.

Yuan D, Wang H, He H, Jia L, He Y, Wang T, Zeng X, Li Y, Li S, Zhang C (2014). Protective effects of total flavonoids from Epimedium on the male mouse reproductive system against cyclophosphamideinduced oxidative injury by up-regulating the expressions of SOD3 and GPX1. Phytotherapy Research, 28: 88-97. DOI: https://doi.org/10.1002/ptr.4956.

Zhang D, Liu L, Jia Z, Yao X and Yang M (2016). Flavonoids of Herba Epimedii stimulate osteogenic differentiation and suppress adipogenic differentiation of primary mesenchymal stem cells via estrogen receptor pathway. Pharmaceutical Biology, 54: 954-963. DOI: https://doi.org/10.3109/13880209.2015.1079224.
Zhang HF, Yan LH, Zhang QW and Wang ZM (2013). Flavonoids from leaves of Epimedium pubescens. China Journal of Chinese materia medica, 38: 1942-1946. Available at: https://www.ncbi.nlm.nih.gov/pubmed/24066589.

Zhang HF, Yang TS, Li ZZ and Wang Y (2008). Simultaneous extraction of epimedin a, b, c and icariin from Herba epimedii by ultrasonic technique. Ultrasonics Sonochemistry, 15: 376-385. DOI: https://doi.org/10.1016/j.ultsonch.2007.09.002.

Zhang X, Li Y, Yang X, Wang K, Ni J and Qu X (2005). Inhibitory effect of Epimedium extract on s-adenosyl-1-homocysteine hydrolase and biomethylation. Life Sciences, 78: 180-186. DOI: https://doi.org/10.1016/j.lfs.2005.04.057.

Zhao D (2018). Effects estrogen and TGF-b1 on development of chicken primordial and growing follicles. Doctor Zhejiang University. Available

at: http://kns.cnki.net/kns/detail/detail.aspx?FileName $=1018263497$ nh\&DbName $=$ CDFD2018.

Zhao D, Leghari IH, Li J, Mi Y and Zhang C (2018). Isolation and culture of chicken growing follicles in 2- and 3-dimensional models. Theriogenology, 111: 43-51. DOI: https://doi.org/10.1016/j.theriogenology.2018.01.012.

Zhao H, Shan Y, Ma Z, Yu M and Gong B (2019). A network pharmacology approach to explore active compounds and pharmacological mechanisms of Epimedium for treatment of premature ovarian insufficiency. Drug Design, Development and Therapy, 13: 2997-3007. DOI: https://doi.org/10.2147/DDDT.S207823.

Zhou ZP, Feng X, Wang DW, Lan WR, Chen TR and Chen C (2012). Effect of epimedin c and icariin on uterus of ovariectomized mice. Chinese Journal of Gerontology, 32: 3931-3933. Available at: http://kns.cnki.net/kcms/detail/detail.aspx?FileName=GLYZ201203 009\&DbName $=$ CJFQ2012 